\title{
Quantitative Study on the Aging of Kraft Paper in Vegetable Oils
}

\author{
Juan Carcedo, Inmaculada Fernández, Alfredo Ortiz, Fernando Delgado, Carlos \\ J. Renedo and Alberto Arroyo
}

Electrical and Energy Engineering Department

School of Industrial and Telecommunications Engineering, University of Cantabria, Avda. Los Castros, s/n. Santander, Spain

Key words: vegetable oil, mineral oil, paper, aging, Arrhenius, power transformer

The focus of this article is on the values of the activation energy and preexponential factor in the Emsley/Heywood kinetic model as applied to vegetable oil-impregnated paper as a step forward in the quantitative study of the degradation of the paper.

\section{Introduction}

Interest in using vegetable oils as dielectric coolants in power transformers dates back to the early studies on linseed- and castor-based fluids as possible replacements to mineral oil. However, interest in vegetable oils was lost due to their high viscosity and their tendency to oxidize. But, in the early 1990s and due to environmental concerns, the interest in dielectric fluids based on vegetable esters re-emerged. As a result, two vegetable ester based oils were developed; namely, BIOTEMP ${ }^{\circledR}$ developed by ABB and FR3 ${ }^{\circledR}$ developed by Cooper Power Systems.

The behavior of natural esters is not yet known in detail. Because of this, the International Electrotechnical Commission (IEC) created a working group (TC10 PT62975) that is charged with creating a document to define the limits of the parameters that determine the quality of a natural ester-based oil for power transformers. The document is entitled "Use and Maintenance Guidelines of Natural Ester Liquids in Electrical Equipment”.

Over recent years, there have been many published works on the suitability of some vegetable oils as dielectrics and coolants in power transformers [1] - [9]. From the viewpoint of the lifetime of a power transformer, the assessment of the state of the dielectric system is essential. While the replacement or regeneration of oil can be done, replacing the paper is not feasible at all, so one can say that a transformer reaches the end of its life when the paper has degraded to the point of not being unable to withstand the in-service stresses [10].

Among the factors affecting the aging of paper, the nature of the impregnating oil is especially important and some studies on paper aging when impregnated in vegetable oil compared to mineral oil have been reported [11] - [15]. In particular, the degree of polymerization (DP), which is defined as the average number of repeating units (monomers) that are contained in the molecular chain of a polymer, is significant as paper degradation lowers the DP index.

To predict the behavior of the paper and therefore the life of the transformer, various kinetic models of degradation have been proposed; one of them being the Ekenstam model [16], dating from the 1930s, which established a relationship between DP and time [17].

Some years later, the working group formed by A.M. Emsley, R.J. Heywood and G.C. Stevens established a more complex kinetic model based on the Ekenstam model 
but considered the variability of the aging rate [18] - [26], which better fits the experimental results that had been previously obtained with mineral oil-impregnated paper. The parameters that define this more complex model (Emsley/Heywood kinetic model [22]) have been characterized in [19] by an Arrhenius relationship through its activation energy and its corresponding pre-exponential factor.

This article focuses on the values of the activation energy and pre-exponential factor in the Emsley/Heywood kinetic model as applied to vegetable oil-impregnated paper as a step forward in the quantitative study of the degradation of the paper.

\section{Materials and Methods}

Laboratory tests consisting of thermally accelerated aging with Kraft paper impregnated in reference mineral oil (MO) and vegetable oils (VO1 and VO2) were carried out. Table 1 shows the properties of the Kraft paper used in the study as supplied by the manufacturer and Table 2 shows the measured properties of the oils prior to aging.

Table 1. Properties of the Kraft paper used in the study.

\begin{tabular}{|l|l|l|l|}
\hline Property & Unit & Standard & Value \\
\hline Thickness & $\mathrm{mm}$ & & 0.075 \\
\hline Weight & $\mathrm{g} / \mathrm{mm}^{2}$ & & 61 \\
\hline Density & $\mathrm{g} / \mathrm{cm}^{3}$ & \multirow{2}{*}{ IEC 554 } & 0.8 \\
\hline $\begin{array}{c}\text { Breakdown strength } \\
\text { (in air) }\end{array}$ & $\mathrm{kV} / \mathrm{mm}$ & & 7 \\
\hline
\end{tabular}

Table 2. Properties of oils used in the study.

\begin{tabular}{|c|c|c|c|c|c|}
\hline Property & Unit & Standard & MO & VO1 & VO2 \\
\hline Viscosity, 40 ${ }^{\circ} \mathrm{C}$ & $\mathrm{mm}^{2} / \mathrm{s}$ & $\begin{array}{c}\text { ISO 3104 } \\
\text { ASTM D 445 }\end{array}$ & 7.6 & 37 & 39.2 \\
\hline Density, 20 ${ }^{\circ} \mathrm{C}$ & $\mathrm{kg} / \mathrm{dm}^{3}$ & $\begin{array}{c}\text { ISO 12185 } \\
\text { ISO 3675 } \\
\text { ASTM D1298 }\end{array}$ & 0.877 & 0.92 & 0.9128 \\
\hline $\begin{array}{c}\text { Breakdown voltage } \\
(2.5 \mathrm{~mm})\end{array}$ & $\mathrm{kV}$ & IEC 60156 & $40-60$ & $>75$ & 81 \\
\hline Acidity & $\mathrm{mgKOH} / \mathrm{g}$ & $\begin{array}{c}\text { IEC 62021 } \\
\text { ASTM D 974 }\end{array}$ & 0.01 & $<0.05$ & 0.05 \\
\hline $\begin{array}{c}\text { Tan delta } \\
\left(90^{\circ} \mathrm{C} \text { and } 50 \mathrm{~Hz}\right)\end{array}$ & ${ }^{\circ} \mathrm{C}$ & $\begin{array}{c}\text { ISC 60247 } 2719 \\
\text { ASTM D 92 }\end{array}$ & 0.001 & $<0.005$ & 0.0134 \\
\hline $\begin{array}{c}\text { Flash point } \\
\text { Moisture } \\
\text { content }\end{array}$ & $\mathrm{mg} / \mathrm{kg}$ & IEC 60814 & $<20$ & 50 & 332 \\
\hline
\end{tabular}

The sample preparation procedure used in the study was the same as described in [27]. First, strips of Kraft paper $(260 \times 15 \mathrm{~mm})$ were placed in three steel vessels under vacuum for moisture stripping. Next, the vessels were filled with nitrogen for which hygroscopicity aids in the further removal of moisture from the paper and the vessels were heated in an oven at $100^{\circ} \mathrm{C}$ for 24 hours, to attain a moisture content of 
approximately $0.5 \%$. Finally, the vessels were opened, and the three oils poured into each of the three vessels and the vacuum and nitrogen filling processes were repeated.

The prepared samples were oven aged at 110,130 and $150{ }^{\circ} \mathrm{C}$. This temperature range allowed us to perform an accelerated test without the risk of side effects due to pyrolysis or carbonization. The aging period varied on the aging temperature and during aging, the paper samples were removed at different intervals and tested. Because the aging rate increases with temperature, the sampling rate at $150{ }^{\circ} \mathrm{C}$ was more frequent than at $110^{\circ} \mathrm{C}$.

Moreover, as the degradation is more pronounced at the beginning of aging, the last samples were taken at longer time intervals.

\section{Theoretical Considerations}

DP represents the average number of monomers that make up the lengths of polymer chains. Thus, a polymer containing $\mathrm{N}$ monomers and $\mathrm{M}$ molecules will have $\mathrm{Z}$ bonds between the monomers according to the relationship

$$
Z=N-M
$$

and DP can be expressed as

$$
D P=\mathrm{N} / \mathrm{M} \text {. }
$$

Therefore, the number of bonds between molecules $Z_{t}$ at time $t$ is given by

$$
Z_{t}=\mathrm{N}-\mathrm{M}_{\mathrm{t}}=\mathrm{N} \cdot\left(1-\mathrm{M}_{\mathrm{t}} / \mathrm{N}\right)=\mathrm{N} \cdot\left(1-1 / \mathrm{DP}_{\mathrm{t}}\right)
$$

As the paper ages, the number of monomers does not vary over time, but the number of molecules does, as the bonds between monomers are broken. Therefore, the number of bonds at the initial time $\mathrm{Z}_{0}$ is determined according to

$$
Z_{0}=\mathrm{N}-\mathrm{M}_{0}=\mathrm{N} \cdot\left(1-\mathrm{M}_{0} / \mathrm{N}\right)=\mathrm{N} \cdot\left(1-1 / \mathrm{DP}_{0}\right)
$$

At the beginning of the aging process, several bonds between monomers are expected, that is, long polymer chains and thus, a high value DP. Assuming that the rate of chemical reaction, or the breaking of bonds between monomers, depends on the concentration of reactants, or the number of links, the number of bonds $\mathrm{Z}$ will decrease according to

$$
-d Z / d t=k_{1} \cdot \mathrm{Z}
$$

where $\mathrm{k}_{1}$ is the rate of proportionality.

Integrating (5) between the initial time to and t, the basis of the Ekenstam kinetic model is obtained [16]. Thus,

$$
\log \left(1-1 / D P_{0}\right)-\log \left(1-1 / D P_{t}\right)=-k_{1} \cdot t
$$


The major limitation of the model is that it assumes that the rate of proportionality, $\mathrm{k} 1$, is constant. However, as the paper ages, many of the bonds between monomers will break and since their number is limited, broken links will be less likely? From the viewpoint of chemical kinetics, this circumstance results in a progressive decrease in the rate of proportionality, which numerically means k1 cannot be constant. Therefore, it is expected that the proportionality constant $\mathrm{k}_{1}$ decreases with time.

Consider the value of proportionality reduces to a factor $\mathrm{k}_{2}$, thus

$$
-d k_{1} / d t=k_{2} \cdot k_{1}
$$

and the instantaneous value of $\mathrm{k}_{1}$ can be obtained from

$$
k_{1}=k_{10} \cdot \exp \left(-\mathrm{k}_{2} \cdot t\right)
$$

in which $\mathrm{k} 10$ represents the initial value of $\mathrm{k} 1$.

Equation (8) is the basis of the Emsley/Heywood kinetic model [22], whose mathematical form can be obtained by substituting (8) in the differential form of (6) and integrating between the initial instant and an instant $t$, being necessary to consider that when the DP is high enough, the following relationship can be assumed

$$
\log (1-1 / D P) \rightarrow-1 / \mathrm{DP}
$$

Under such conditions, the Emsley/Heywood kinetic model is described by the following

$$
\log \left(1-1 / D P_{0}\right)-\log \left(1-1 / D P_{t}\right)=\frac{k_{10}}{k_{2}} \cdot\left(1-e^{-k_{2} \cdot t}\right)
$$

The DP value over time has been measured through laboratory tests of the three oils at three different temperatures, according to the Standard, and a numerical analysis using MS Excel ${ }^{\circledR}$ and MATLAB ${ }^{\circledR}$ allows us to obtain the values of $\mathrm{k}_{10}$ and $\mathrm{k}_{2}$ that best fit (10).

It is then assumed that of $\mathrm{k}_{10}$ and $\mathrm{k}_{2}$ can be defined by an Arrhenius relationship, thus

$$
k_{i}=A_{i} \cdot \exp \left(-\mathrm{E}_{\mathrm{a}, \mathrm{i}} /(R \cdot T)\right)
$$

$$
\begin{array}{ll}
\text { where } & \\
\mathrm{k}_{\mathrm{i}} & \text { factor }\left(\mathrm{k}_{10} \text { and } \mathrm{k}_{2}\right) \\
\mathrm{A}_{\mathrm{i}} & \text { pre-exponential factor } \\
\mathrm{E}_{\mathrm{a}, \mathrm{i}} & \text { activation energy }(\mathrm{J} / \mathrm{mol}) \\
\mathrm{R} & \text { gas constant }(8,3143 \mathrm{~J} / \mathrm{mol} / \mathrm{K}) \\
\mathrm{T} & \text { temperature }(\mathrm{K})
\end{array}
$$

Taking logarithms of (11) a linear function $k_{i}=f(1 / T)$ whose slope is $-E_{a, j} / R$ and intercept is $\log A_{i}$. Thus,

$$
\log \left(k_{i}\right)=\log A_{i}-\mathrm{E}_{\mathrm{a}, \mathrm{i}} /(R \cdot T)
$$


Separate relationship for each of the tested oils is obtained from the three temperatures. The activation energy and pre-exponential factor is obtained which then defines the relationship. At any operating temperature, the values of the factors $\mathrm{k}_{10}$ and $\mathrm{k} 2$ that define the paper degradation kinetic model for the oil is obtained.

\section{Results and discussion}

Figure 1 shows the decrease of DP with time when the Kraft paper was impregnated with the three types of oil and subjected to thermally accelerated aging at three temperatures. The results agree with that reported in previous research [28] showing a decrease of DP over time and this deterioration being more pronounced at the beginning of the process and at higher temperatures. The logarithmic difference shown in (10) was obtained and these results are shown in Figure 2.

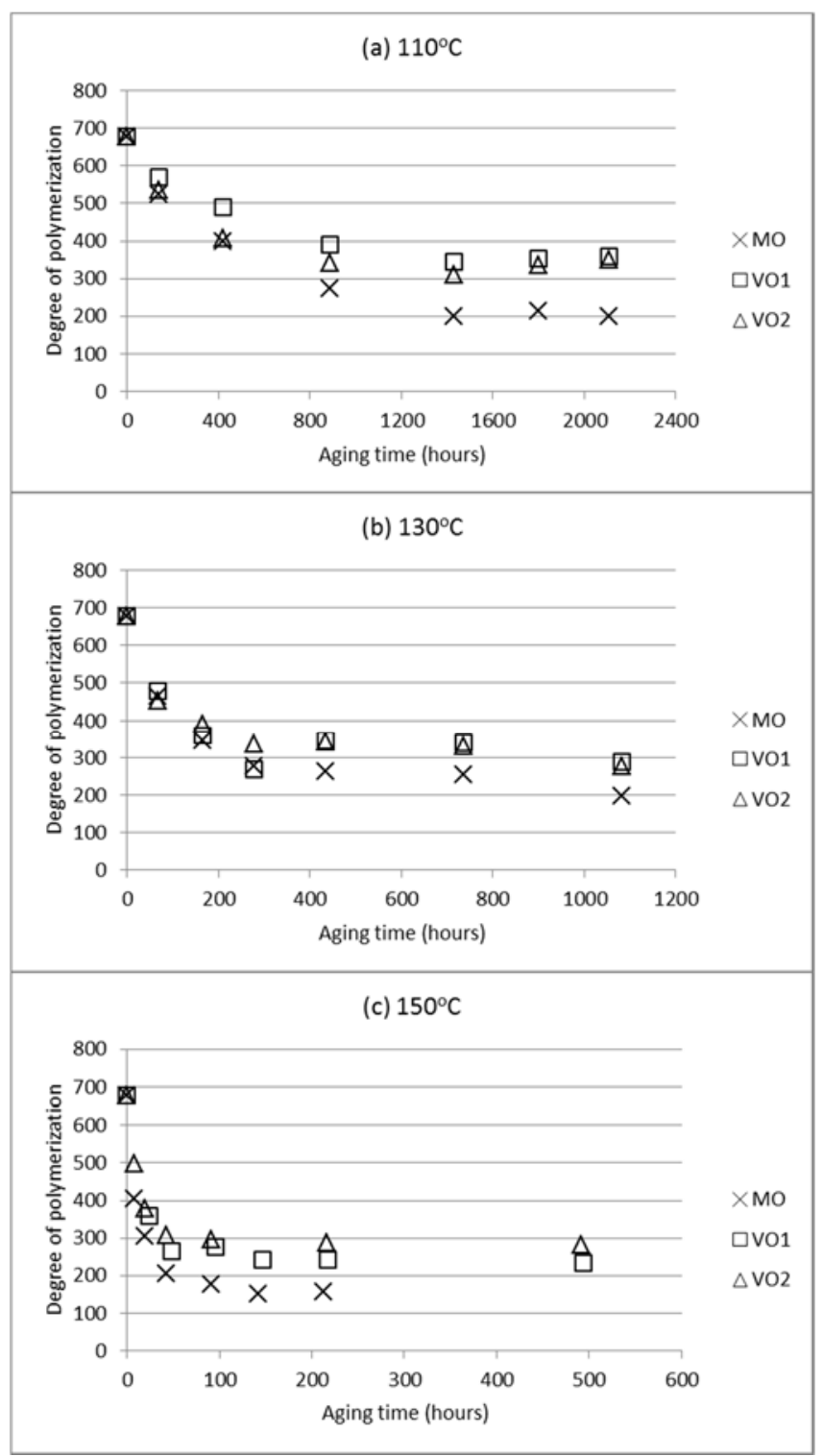

Figure 1. Decrease in the degree of polymerization of Kraft paper with aging time for MO, VO1 and VO2 oils. 


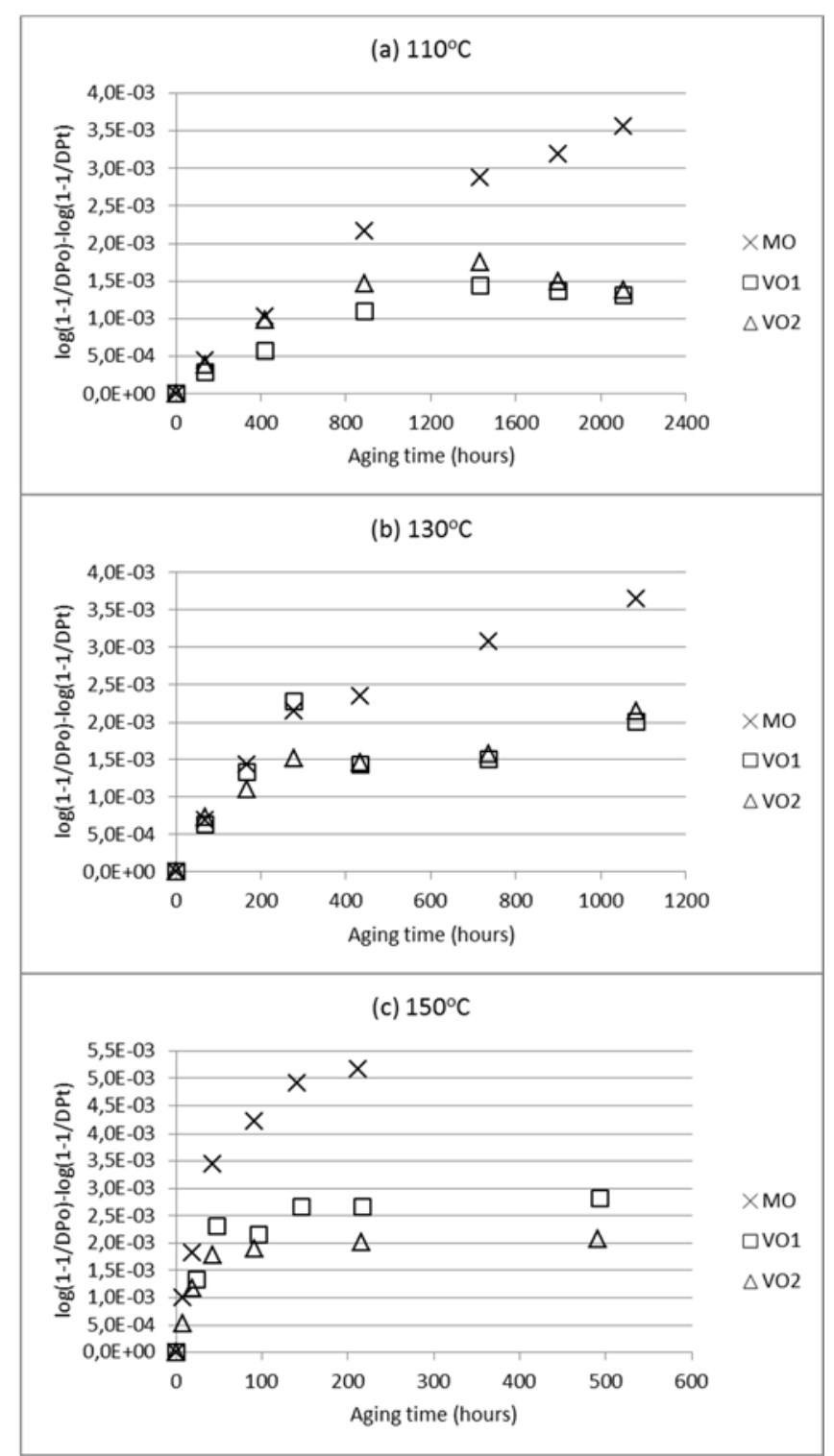

Figure 2. Decrease in the degree of polymerization in the form of equation (10) of Kraft paper with aging time for MO, VO1 and VO2 oils.

Except at the very beginning of the aging process, Figure 2 shows a significant departure of the experimentally obtained values of DP with respect to those expected from (6). However, this simplified Ekenstam kinetic model described by (6) could be useful in obtaining the factor $\mathrm{k}_{10}$ from the first two samples. The fit of the data to (10) was performed using MATLAB ${ }^{\circledR}$ and the results are summarized in Table 3 for each oil and at each temperature.

The numerical values of $\mathrm{k}_{10}$ and $\mathrm{k}_{2}$ in Table 3 allow us to predict the aging rate of paper, in terms of DP, but only at the three temperatures tested. However, the aim is to determine the values of $\mathrm{k}_{10}$ and $\mathrm{k}_{2}$ for each oil type and at any operating temperature. Assuming that factors $\mathrm{k}_{10}$ and $\mathrm{k}_{2}$ can be expressed by (11), it is possible to obtain the relationship that fits (12) for each type of oil. The lines obtained are plotted in Figure 3 and from them the values of activation energy and pre-exponential factor for each type of oil have been obtained (Table 4).

Finally, in Figure 4, the DP values obtained experimentally are compared to those calculated through the Emsley/Heywood model with the numerical values of Table 4. 
Table 3. Rate of proportionality constants $\mathrm{k}_{10}$ and $\mathrm{k}_{2}$ in equation 10 from experimental data as in Figure 2.

\begin{tabular}{|c|c|c|c|c|}
\hline \multicolumn{2}{|c|}{ OIL } & MO & VO1 & VO2 \\
\hline \multirow{3}{*}{$110^{\circ} \mathrm{C}$} & $\mathrm{k} 10$ & $3.084 \mathrm{E}-06$ & $2.149 \mathrm{E}-06$ & $3.845 \mathrm{E}-06$ \\
\cline { 2 - 5 } & $\mathrm{k} 2$ & $6.519 \mathrm{E}-04$ & $1.450 \mathrm{E}-03$ & $2.791 \mathrm{E}-03$ \\
\cline { 2 - 5 } & $\mathrm{R}^{2}$ & 0.9976 & 0.9788 & 0.9142 \\
\hline \multirow{3}{*}{$130^{\circ} \mathrm{C}$} & $\mathrm{k} 2$ & $2.710 \mathrm{E}-03$ & $7.876 \mathrm{E}-03$ & $5.374 \mathrm{E}-03$ \\
\cline { 2 - 5 } & $\mathrm{k}_{10}$ & $1.008 \mathrm{E}-05$ & $1.418 \mathrm{E}-05$ & $9.981 \mathrm{E}-06$ \\
\hline \multirow{3}{*}{$150^{\circ} \mathrm{C}$} & $\mathrm{k} 2$ & $2.374 \mathrm{E}-02$ & $2.742 \mathrm{E}-02$ & $3.815 \mathrm{E}-02$ \\
\cline { 2 - 5 } & $\mathrm{k}_{10}$ & $1.198 \mathrm{E}-04$ & $7.352 \mathrm{E}-05$ & $7.937 \mathrm{E}-05$ \\
\cline { 2 - 5 } & $\mathrm{R}^{2}$ & 0.9942 & 0.9598 & 0.9898 \\
& & & & \\
\hline
\end{tabular}

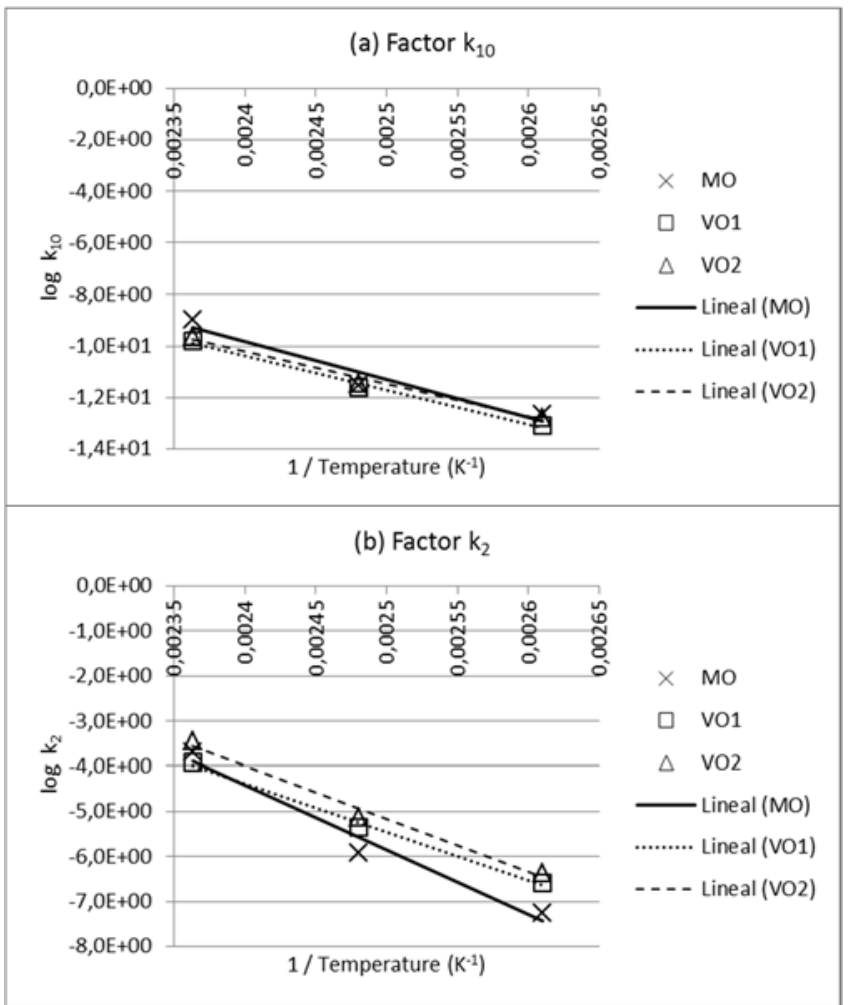

Figure 3. Rate of proportionality constants $k_{10}$ and $k_{2}$ plotted using equation (12) for MO, VO1 and VO2 oils. 
Table 4. Activation energy Ea and pre-exponential factor A for each type of oil for rate of proportionality constants $\mathrm{k}_{10}$ and $\mathrm{k}_{2}$ using equation (11).

\begin{tabular}{|l|c|c|c|c|}
\hline \multicolumn{2}{|c|}{} & MO & VO1 & VO2 \\
\hline \multirow{4}{*}{$\mathrm{k}_{10}$} & $\mathrm{E}_{\mathrm{a}}(\mathrm{kJ} / \mathrm{mol})$ & 122.51 & 119.08 & 101.31 \\
\cline { 2 - 5 } & $\mathrm{A}\left(\mathrm{h}^{-1}\right)$ & $1.228 \mathrm{E}+11$ & $3.727 \mathrm{E}+10$ & $2.041 \mathrm{E}+08$ \\
\cline { 2 - 5 } & $\mathrm{R}^{2}$ & 0.9482 & 0.9999 & 0.9440 \\
\hline \multirow{3}{*}{$\mathrm{k} 2$} & $\mathrm{E} a(\mathrm{~kJ} / \mathrm{mol})$ & 120.64 & 99.23 & 87.33 \\
\cline { 2 - 5 } & $\mathrm{A}\left(\mathrm{h}^{-1}\right)$ & $1.575 \mathrm{E}+13$ & $5.134 \mathrm{E}+10$ & $1.790 \mathrm{E}+09$ \\
\cline { 2 - 5 } & $\mathrm{R}^{2}$ & 0.9783 & 0.9966 & 0.9075 \\
& & & & \\
\hline
\end{tabular}

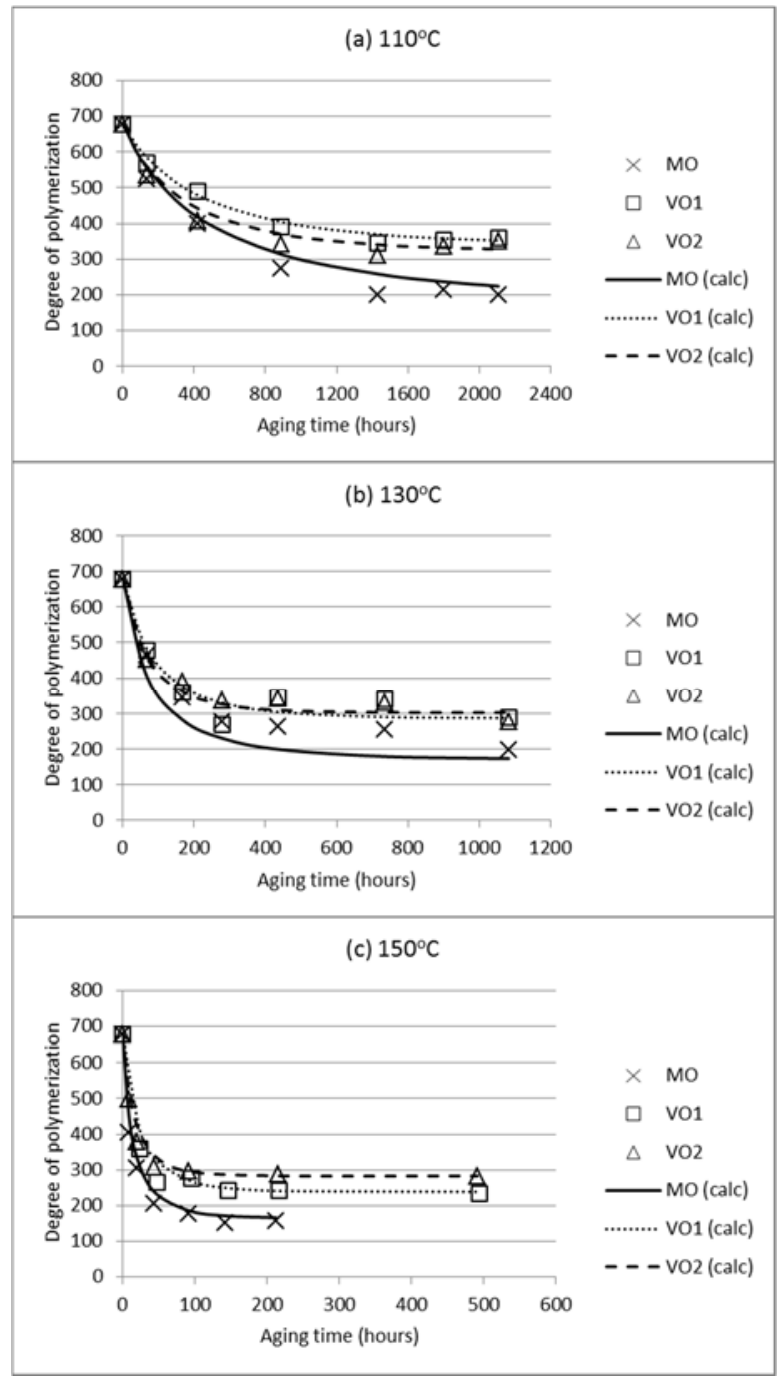

Figure 4. Experimental DP values compared to calculated values through the Emsley/Heywood model with the numerical values of Table 4. 


\section{Conclusions}

The measured DP of all three oils examined in this aging study show a strong dependence on the temperature of the test. Significant deterioration of paper takes place with temperature during the initial aging period as observed by a notable decrease in DP which is followed by a relatively stable DP with further aging. These observations are consistent with other qualitative results published previously by various authors. However, the results on activation energies and pre-exponential factors defining the kinetic model make it possible to quantitatively estimate the DP in any of the three oils and at any operating temperature.

When a power transformer is operating under normal conditions, that is, at a lower temperature than that necessary to carry out accelerated aging tests, the DP value may stabilize well above 200, which is the most commonly used threshold to determine the end of life of the paper. For example, with an operating temperature of $75^{\circ} \mathrm{C}$, the paper impregnated in MO mineral oil would reach a DP value of 200 after 18 years, whereas the DP of the paper impregnated in VO1 or VO2 vegetable oils would stabilize at a value above 400. Addressing the issue from another point of view, the paper impregnated in VO1 could theoretically operate at a temperature of $175^{\circ} \mathrm{C}$ with a stabilized DP value of 200 , or at a temperature of $210^{\circ} \mathrm{C}$ in the case of VO2. However, such high temperatures would not be feasible operating conditions, as other phenomena like carbonization of the paper would occur.

\section{References}

[1] D.C. Abeysundara, C. Weerakoon, J.R. Lucas, K.A.I. Gunatunga, and K.C. Obadage, "Coconut oil as an alternative to transformer oil", Engineering Research Unit Symp., pp. 1-11, 2001.

[2] M. Hemmer, R. Badent, and A. Schwab, "Electrical properties of rape-seed oil", Annu. Rep. IEEE Conf. Electr. Insul. Dielectr. Phen., pp. 83-86, 2002.

[3] M. Hemmer, R. Badent, and T. Leibfried, "Investigation of the suitability of commercially available bio-oils as insulating liquid”, Annu. Rep. IEEE Conf. Electr. Insul. Dielectr. Phen. pp. 64-67, 2003.

[4] Y. Bertrand, and L.C. Hoang, "Vegetal oils as substitute for mineral oils", Proc. 7th Int. Conf. Prop. Appl. Dielectr. Mat., vol. 2, pp. 491-494, 2003.

[5] J. Li, S. Grzybowski, Y. Sun, and X. Chen, "Dielectric properties of rapeseed oil paper insulation”, Annu. Rep. IEEE Conf. Electr. Insul. Dielectr. Phen., pp. 500-503, 2007.

[6] C.T. Duy, A. Denat, O. Lesaint, N. Bonifaci, and Y. Bertrand, "Moisture and temperature effects on conduction and losses in modified rape-seed insulating oil", Annu. Rep. IEEE Conf. Electr. Insul. Dielectr. Phen., pp. 647-650, 2007.

[7] A.A. Abdelmalik, A.P. Abbott, J.C. Fothergill, S.J. Dodd, and R.C. Harris. "Synthesis of a base-stock for electrical insulating fluid based on palm kernel oil", Ind. Crops and Prod., vol 33, pp. 532-536, 2011.

[8] I. Fernández, A. Ortiz, F. Delgado, C.J. Renedo, and S. Pérez. “Comparative evaluation of alternative fluids for power transformers", Elect. Power Sys. Res., vol. 98, pp. 58-69, 2013.

[9] M. Castillero, R. Asano, and S. A. Page. "Transformadores con ésteres naturales como líquido aislante dieléctrico”, Dyna, vol. 87, no. 6, pp. 633-638, 2012.

[10] L. Pettersson. "Estimation of the remaining service life of power transformers and their insulation”, Electra, no. 133, pp. 65-71, 1990. 
[11] H. Borsi. "Gassing behaviour of different insulating liquids for transformers", ELECTRA-CIGRE, pp. 21-42, 2000.

[12] I. Khan, Z. Wang, J. Dai, I. Cotton, and S. Northcote, "Fault gas generation in ester based transformer fluids and dissolved gas analysis", IEEE Int. Conf. Cond. Mon. Diag., pp. 909-913, 2008.

[13] L. Lewand, "Laboratory evaluation of several synthetic and agricultural-based dielectric liquids”, Doble Int. Client Conf., vol. 5, 2001.

[14] T.V. Oommen, C.C. Claiborne, and J.T. Mullen, "Biodegradable electrical insulation fluids”, IEEE Electr. Insul. Conf., pp. 465-468, 1997.

[15] T.V. Oommen. "Vegetable oils for liquid-filled transformers", IEEE Elect. Insul. Mag., vol. 18, no. 1, pp. 6-11, 2002.

[16] A. Ekenstam. "The behaviour of cellulose in mineral acid solutions: kinetic study of the decomposition of cellulose in acid solutions", Ber. Deutschen Chem. Gesellschaft, vol. 69, p. 540-553, 1936.

[17] W. Kuhn. "The kinetics of the decomposition of high molecular chains", Ber. Deutschen Chem. Gesellschaft, vol. 63, pp. 1503-1509, 1930.

[18] A.M. Emsley, and G.C. Stevens. "Kinetics and mechanisms of the low-temperature degradation of cellulose”, Cellulose, vol. 1, no. 1, pp. 26-56, 1994.

[19] A.M. Emsley, X. Xiao, R.J. Heywood, and M. Ali. "Degradation of cellulosic insulation in power transformers. Part 3: Effects of oxygen and water on ageing in oil”, IEE Proc. Sci. Meas. Technol., vol. 147, no. 3, pp. 115-119, 2000.

[20] A.M. Emsley, and G.C. Stevens, "A reassessment of the low temperature thermal degradation of cellulose”, $6^{\text {th }}$ Int. Conf. Dielectr. Mat. Meas. Appl., pp. 229-232, 1992.

[21] A.M. Emsley, and G.C. Stevens. "Review of chemical indicators of degradation of cellulosic electrical paper insulation in oil-filled transformers", IEE Proc. on Sci. Meas. Technol., vol. 141, no. 5, pp. 324-334, 1994.

[22] A.M. Emsley, R.J. Heywood, M. Ali, and C.M. Eley. "On the kinetics of degradation of cellulose”, Cellulose, vol. 4, pp. 1-5, 1997.

[23] A.M. Emsley, X. Xiao, R.J. Heywood, and M. Ali. "Degradation of cellulosic insulation in power transformers. Part 2: Formation of furan products in insulating oil", IEE Proc. Sci. Meas. Technol., vol. 147, no. 3, pp. 110-114, 2000.

[24] A.M. Emsley, R.J. Heywood, M. Ali, and X. Xiao, "Degradation of cellulosic insulation in power transformers. Part 4. Effects of ageing on the tensile strength of paper”, IEE Proc. Sci. Meas. Technol., vol. 147, no. 6, pp. 285-290, 2000.

[25] G.C. Stevens, H. Herman, and P.J.S. Baird, "Insulation Condition Assessment through Spectroscopic and Chemometrics Analysis”, IEEE Int. Conf. Sol. Dielectr., pp. 717-720, 2007.

[26] R.J. Heywood, A.M. Emsley, and M. Ali. "Degradation of cellulosic insulation in power transformers. Part 1 . Factors affecting the measurement of the average viscometric degree of polymerisation of new and aged electrical papers”, IEE Proc. Sci. Meas. Technol., pp. 86-90, 2000.

[27] J. Carcedo, I. Fernández, A. Ortiz, F. Delgado, C.J. Renedo and C. Pesquera, “Aging Assessment of Dielectric Vegetable Oils”, IEEE Elect. Insul. Mag., vol. 31, no. 6, pp. 13-21, 2015.

[28] D.H. Shroff, and A.W. Stannett, "A review of paper aging in power transformers", IEE Proc. Gen. Tran. Dist., vol. 132, no. 6, pp. 312-319, 1985. 


\begin{tabular}{|c|c|}
\hline & $\begin{array}{l}\text { Juan Carcedo received the MSc degree in Industrial Engineering } \\
\text { in } 2004 \text { and worked as a freelance engineer for ten years and as a } \\
\text { part time Lecturer at the University of Cantabria from } 2009 \text { to } 2014 \text {. } \\
\text { He received the PhD degree in } 2015 \text { and currently he is Assistant } \\
\text { Lecturer of the Electrical and Energy Engineering Department in the } \\
\text { School of Industrial Engineering at the University of Cantabria. His } \\
\text { main research topic is the study of transformer ageing and insulating } \\
\text { oils and paper. }\end{array}$ \\
\hline & $\begin{array}{l}\text { Inmaculada Fernández received the MSc degree in Chemical } \\
\text { Engineering in } 2004 \text { and the PhD degree in } 2009 \text { from the } \\
\text { University of Cantabria, Spain. Currently, she is an Assistant } \\
\text { Lecturer in the Electrical and Energy Engineering Department at the } \\
\text { University of Cantabria. She has published two chapters in } \\
\text { international books, over } 20 \text { works in national and international } \\
\text { conferences, and } 9 \text { papers in journals included in the Journal of } \\
\text { Citation Report. Her main research topic is the energy conservation. }\end{array}$ \\
\hline & $\begin{array}{l}\text { Alfredo Ortiz graduated with a PhD in Electrical Engineer at } \\
\text { University of Cantabria in } 2005 \text {. He has published six chapters in } \\
\text { international books, over } 50 \text { works in international conferences and } \\
21 \text { papers in journals included in the Journal of Citation Report. He } \\
\text { has acted as reviewer for several international journals included in } \\
\text { the Journal of Citation Report. He belongs to national } \\
\text { (AEN/CTN207/SC14 and AEN/CTN207/SC10) and international } \\
\text { committees (CENELEC/TC14/WG29, IEC60076-20 and } \\
\text { IEC/TC10/WG33) for standardization in the field of power } \\
\text { transformers and alternative dielectric fluids. Currently, he is the } \\
\text { Head of Electrical and Energy Engineering Department at the } \\
\text { University of Cantabria. }\end{array}$ \\
\hline & $\begin{array}{l}\text { Carlos J. Renedo received the MSc degree in Industrial } \\
\text { Engineering in } 1997 \text { and the PhD degree in } 2002 \text { from the } \\
\text { University of Cantabria, Spain. Currently, he is an Associate } \\
\text { Professor in the Electrical and Energy Engineering Department at } \\
\text { the University of Cantabria. He has published over } 50 \text { works in } \\
\text { international conferences and } 24 \text { papers in journals included in the } \\
\text { Journal of Citation Report. His main research topic is in energy } \\
\text { conservation. }\end{array}$ \\
\hline & $\begin{array}{l}\text { Fernando Delgado received the MSc degree in Industrial } \\
\text { Engineering in } 1998 \text { and the PhD degree in } 2011 \text { from the } \\
\text { University of Cantabria, Spain. Currently, he is an Associate } \\
\text { Professor in the Electrical and Energy Engineering Department at } \\
\text { the University of Cantabria. He has published over } 25 \text { works in } \\
\text { international conferences and } 13 \text { papers in journals included in the } \\
\text { Journal of Citation Report. Currently his main research topic is the } \\
\text { study of the alternative dielectric liquids in power transformers. }\end{array}$ \\
\hline
\end{tabular}




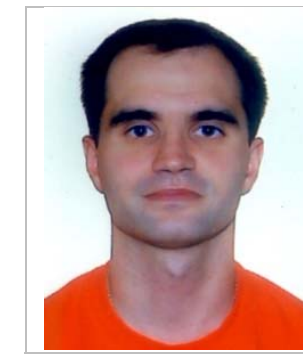

Alberto Arroyo received the $\mathrm{PhD}$ in electrical engineering at University of Cantabria in 2012. Currently, he is an Assistant Lecturer in the Electrical and Energy Engineering Department at the University of Cantabria. He has published 2 chapters in international books, 15 works in international conferences and 7 papers in journals included in the Journal of Citation Report. He has worked as an electrical engineer at Gamesa Electric. 